\title{
Waardenburg-Shah syndrome
}

INSERM

\section{Source}

INSERM. (1999). Orphanet: an online rare disease and orphan drug data base.

Waardenburg-Shah syndrome. ORPHA:897

Waardenburg-Shah syndrome (WSS), also known as Waardenburg syndrome type 4 (WS4) is characterized by the association of Waardenburg syndrome (sensorineural hearing loss and pigmentary abnormalities) and Hirschsprung disease (ag ang lionic megacolon). 